Mental distress among U.S. adults during the COVID-19 pandemic

Jean M. Twenge

San Diego State University

Thomas E. Joiner

Florida State University

Draft version 5/15/20. This paper has not been peer reviewed.

Author note: The authors thank Hannah Lemon and Katherine G. Louden for their assistance with statistical calculations. This research received no funding. Address correspondence to Jean M. Twenge, Department of Psychology, San Diego State University, 5500 Campanile Drive, San Diego, CA 92182-4611; or by electronic mail to jtwenge@sdsu.edu. ORCID: 0000-0002-65428281 


\begin{abstract}
Background: The COVID-19 pandemic substantially changed daily life in ways that may impact mental health. Method: This study compared a nationally representative online sample of 2,032 U.S. adults in late April 2020 to 19,330 U.S. adult internet users who participated in the 2018 National Health Interview Survey (NHIS) using the Kessler-6 scale of mental distress in the last 30 days. Results: Compared to the 2018 NHIS sample, U.S. adults in April 2020 were eight times more likely to fit criteria for serious mental distress $(27.7 \%$ vs. $3.4 \%)$ and three times more likely to fit criteria for moderate or serious mental distress $(70.4 \%$ vs. $22.0 \%$ ). Differences between the 2018 and 2020 samples appeared across all demographic groups, with larger differences among younger adults and those with children in the household. Limitations: Although the samples were nationally representative and demographically similar, they varied in sampling strategy and method of administration. Conclusions: These considerable levels of mental distress may portend substantial increases in diagnosed mental disorders and in the morbidity and mortality associated with them.
\end{abstract}

KEYWORDS: MENTAL DISTRESS; COVID-19; ANXIETY; DEPRESSION; SOCIAL ISOLATION 


\section{Mental distress among U.S. adults during the COVID-19 pandemic}

The spread of COVID-19 in the U.S. upended daily life for many Americans beginning in March 2020. Many employees were asked to work remotely; restaurants, stores, parks and beaches closed; schools and universities shuttered their campuses and moved classes online; travel restrictions were imposed; meetings and events were cancelled; and many states and cities imposed stay-at-home orders asking residents to leave home only for essential tasks (e.g.,

Chavez et al., 2020). News stories covered the ever-increasing number of cases and deaths from the virus (Shammas, 2020), and consumers faced shortages of household goods (Kavilanz \& Yukevich, 2020). At the same time, unemployment soared to levels not seen since the Great Depression in the 1930s (Morath, 2020), and gun-related FBI background checks surged to a historically high level (Johnson \& Link, 2020).

Thus, between early March and late April 2020, Americans experienced a confluence of economic stressors, social isolation, health concerns, and practical risks and difficulties. All of these factors have been connected to an increased incidence of mental health disorders in past research, and there is considerable concern about increases related to the COVID-19 pandemic (Reger, Stanley, \& Joiner, 2020). For example, social isolation is a very well-characterized precursor of a number of mental health problems, including major depressive disorder (Barger et al., 2014), anxiety disorders (e.g., Lim et al., 2016), and suicidal behavior (Calati et al., 2019; Van Orden et al., 2010), including suicide death (Robins, 1981). The same is true of factors such as work loss and physical health issues (e.g., Russell, Joiner, \& Turner, 2009).

This has created speculation that the prevalence of mental health issues increased sharply during 2020 (Pfefferbaum \& North, 2020; Reger et al., 2020; Zarefsky, 2020). Anecdotal reports have surfaced of more people seeking help from psychiatrists (Graves, 2020) as well as reports 
of large increases in those contacting the Disaster Distress Helpline (Levine, 2020), the Suicide Crisis Line in Los Angeles (Bharath 2020), and the Crisis Text Line (Lakhani, 2020). There is speculation that some groups, such as parents and younger adults, will suffer more than others (Brenan, 2020; Jervis, 2020; Reyes, 2020). Survey results suggest the general public is concerned about social isolation and mental health during the pandemic, with many believing the crisis has affected their mental health (Benenson Strategy Group, 2020; Brenan, 2020; Holmes et al., 2020). However, these subjective perceptions have not yet been verified by empirical comparisons; to our knowledge, no study has compared mental distress in the U.S. before and during the pandemic. It thus remains unknown whether levels of mental distress were higher in spring 2020 compared to previous years, and in which groups. Research is needed to inform risk assessment strategies, intervention and prevention targets, and health and public policy regarding mental health. Given the already historically high rates of depression, non-suicidal self-injury, and suicide in the U.S. pre-pandemic (Drapeau \& McIntosh, 2020; Spiller, 2019; Twenge et al., 2019), mental health was already viewed with some urgency as a public health matter, and the pandemic has only intensified this urgency.

Therefore, we compared a nationally representative sample of U.S. adults in late April 2020 to U.S. adults in the 2018 National Health Interview Survey, the most recent year of data available (NHIS, 2020). Both surveys included the Kessler-6 (K6), a commonly used and validated measure of mental distress. The K6 is a widely used screening tool for serious mental distress that shows substantial concordance with DSM structured clinical interviews (Kessler et al., 2003, 2010). The K6 is an especially revealing glimpse into mood disorders and anxiety disorders. Regarding mood disorders, item content covers intractable sadness, a cardinal symptom of many mood disorder presentations, and hopelessness, a key symptom of persistent 
depressive disorder. Regarding anxiety disorders, the K6 includes nervousness, restlessness, and fidgetiness, valid indicators of generalized anxiety disorder. This study aims to provide a preliminary view of the mental health of U.S. adults during the COVID-19 pandemic, both overall and by demographic groups including age, gender, race, region, marital status, and the presence of children.

\section{Method}

\section{Participants}

The NHIS is conducted by the National Center for Health Statistics to track the health of the general U.S. population using a multistage area probability design to draw a representative sample of noninstitutionalized U.S. citizens age 18 and over. Participation is voluntary and data are collected through a personal household interview conducted by U.S. Census Bureau employees. The response rate in 2018 was $70 \%$, with $n=24,683$ (NHIS, 2020). The data are publicly available, with the 2018 data the most recent available. NHIS asks participants "Do you use the Internet?" We employed the final weighting variable in the NHIS file designed to make the sample nationally representative. To make the 2018 data more comparable with the 2020 online sample, we selected the $78.9 \%$ of participants in the 2018 NHIS $(81.8 \%$ when weighted) who answered "yes" ( $n=19,330$ with complete data on the distress measure).

The 2020 sample of U.S. adults was obtained from Luc.id, an online survey panel that collects nationally representative samples for social science research using advance screening for gender, race, age, and region (Ackerman, 2019; Coppock \& McClellan, 2019). This recruiting platform has previously been used for COVID-19 related research (Bursztyn et al., 2020). The 2020 survey was reviewed by the San Diego State University Institutional Review Board and declared exempt, and informed consent was obtained from participants. After reading the consent 
form, 97.5\% agreed to participate. Participants completed the survey on April 27, 2020 ( $n=$ 2,032 with complete data on the distress measure). With government stay-at-home orders beginning in mid- to late March, most U.S. residents had experienced life changes for more than a month at the time of the survey.

\section{Measures}

Demographic characteristics. Both surveys collected demographic information on participants, including age, gender, race, Hispanic ethnicity, U.S. region, marital status, and the presence of children under age 18 in the household. The 2020 Luc.id sample was comparable to the NHIS 2018 sample of internet users on these variables (see Table 1).

Income was asked differently in the two samples (yearly earnings in NHIS and yearly household income in Luc.id) so cannot be directly compared. Among NHIS 2018 participants, $4.8 \%$ earned less than $\$ 4,999,4.5 \%$ between $\$ 5,000$ and $\$ 9,999,5.0 \%$ between $\$ 10,000$ and $\$ 14,999,5.8 \%$ between $\$ 15,000$ and $\$ 19,999,5.8 \%$ between $\$ 20,000$ and $\$ 24,999,11.1 \%$ between $\$ 25,000$ and $\$ 34,999,9.7 \%$ between $\$ 35,000$ and $\$ 44,999,8.8 \%$ between $\$ 45,000$ and $\$ 54,999,6.7 \%$ between $\$ 55,000$ and $\$ 64,999,5.2 \%$ between $\$ 65,000$ and $\$ 74,999$, and $19.7 \%$ $\$ 75,000$ or more. Among the 2020 Luc.id participants, $14.5 \%$ had a household income of less than $\$ 14,999,10.4 \%$ between $\$ 15,000$ and $\$ 24,999,8.9 \%$ between $\$ 25,000$ and $\$ 34,999,15.2 \%$ between $\$ 25,000$ and $\$ 49,999,17.0 \%$ between $\$ 50,000$ and $\$ 74,999,11.9 \%$ between $\$ 75,000$ and $\$ 99,999,11.6 \%$ between $\$ 100,000$ and $\$ 149,999,5.8 \%$ between $\$ 150,000$ and $\$ 199,999$, and $4.6 \% \$ 200,000$ or more.

Mental distress. The Kessler-6 is a valid and reliable scale (Kessler et al., 2002) that asks respondents how frequently they experienced symptoms of mental distress during the past 30 days. The 2020 survey employed the wording used in NHIS 2018: "During the PAST 30 
DAYS, how often did you feel ... 1) so sad that nothing could cheer you up, 2) nervous, 3) restless or fidgety, 4) hopeless, 5) that everything was an effort, 6) worthless. Response choices were recoded as: "all of the time" $=4$, "most of the time" $=3$, "some of the time" $=2$, "little of the time" $=1$, and "none of the time" = 0. Cronbach's alpha was .83 in NHIS 2018 and .91 in the 2020 Luc.id sample. The possible range of scores on the K6 was 0 to 24 . Scores of 13 and over indicate serious mental distress and scores of 5 and over indicate moderate or serious mental distress (Prochaska et al., 2012).

\section{Procedure}

We compared the 2018 and 2020 samples on the K6 in three ways: Using means and the effect size $d$ (difference in standard deviations), comparing the percentage fitting criteria for serious mental distress using relative risk (RR) and 95\% confidence intervals (CIs), and comparing the percentage fitting criteria for moderate or serious mental distress using $\mathrm{RR}$ and 95\% CIs. We compared the 2018 and 2020 samples overall and within demographic groups.

\section{Results}

U.S. adults in late April 2020 reported substantially higher mental distress on the K6 than those in 2018, $d=1.48$ (see Table 2). More than one in four adults in April 2020 (27.7\%) fit criteria for serious mental distress, eight times as many as in 2018, RR $=8.13$ (95\% CI: 7.34, 9.01; compared to $3.4 \%$ in 2018). A substantial majority of the 2020 sample, $70.4 \%$, reported moderate or serious distress, three times as many as in $2018(22 \%), \mathrm{RR}=3.20(3.08,3.33)$. Thus, mental distress was considerably more prevalent during the COVID-19 pandemic compared to two years prior.

The differences between the 2018 and 2020 samples appeared across all demographic groups, including age groups, gender, race, Hispanic ethnicity, marital status, and having 
children in the household. There were larger differences in 2018 vs. 2020 among younger people and among those with children in the household (see Table 3 and Figures 1 and 2) as well as for married individuals and Asians. (In some cases, low $n$ within groups means results should be interpreted with caution.)

The differences between the 2018 and 2020 samples appeared across all six items of the K6, with the largest differences in feeling hopeless, sad, and worthless (see Table 4 and Figure 3). The percentage who reported feeling nervous some, most, or all of the time in the last 30 days was nearly three times higher in 2020 (57.6\%) than in 2018 (20.6\%), with similar differences for feeling restless (56.6\% vs. $21.9 \%)$ and that everything was an effort (51.3\% vs. $18.2 \%)$. The 2020 participants were more than four times more likely to report feeling sad (46.1\% vs. 10.8\%), and more than five times more likely to feel hopeless $(37.8 \%$ vs. $6.9 \%)$ or worthless $(32.9 \%$ vs. $5.6 \%)$

\section{Discussion}

More than one out of four U.S. adults in late April 2020, during the COVID-19 pandemic, fit criteria for serious mental distress, eight times more than in a demographically similar sample in 2018. Mean distress differed by 1.48 standard deviations, well above the $d=$ .80 often cited as the cutoff for a large effect size. More than two-thirds of the 2020 sample, $70.4 \%$, displayed moderate or serious mental distress on the K6.

These extraordinarily large rates of mental distress have substantial implications for psychological well-being and mental health. Access to quality mental health care, already a challenge pre-pandemic for many, was greatly complicated by stay-at-home orders as well as by pragmatic issues at health care facilities and offices. Telehealth approaches may offset these complications somewhat and have practical advantages such as no requirement of transportation. 
It is helpful that regulatory burdens on practitioners have been eased at the federal level and by many states, but telehealth requires online fluency and access that not all health care providers or their patients possess, and some state regulatory obstacles remain (Conrad et al., 2020).

All symptoms on the K6 showed quite clear differences between the 2018 and 2020 samples, with the latter clearly more symptomatic. The relative specific symptom pattern of very substantial effects for sadness, hopelessness, and worthlessness, and a somewhat less pronounced (though still large) effect for everything being an effort deserves comment. With regard to suicide risk, the very low energy and sense of depletion that can characterize a condition such as major depressive disorder can undermine the substantial suicide risk that the other aspects of the condition can impart. When anergia abates, yet other symptoms do not, suicide risk becomes potentially very concerning (Meehl, 1973; Stanley, Yancey, Patrick, \& Joiner, 2018). In the samples studied here, two suicide-related symptoms, hopelessness and worthlessness, showed among the highest increases from 2018 to 2020, whereas a symptom related to energy (everything being an effort) showed among the lowest. A person who feels hopeless, sad, and worthless but who retains some resources related to energy presents a worrisome risk profile, especially at a time when firearm sales in the U.S. are at an all-time high.

Differences in mental distress between 2018 and 2020 were larger among younger adults, Asians, married individuals, and those with children in the household. We can only speculate as to why these groups may have been more affected. Younger adults were more likely to lose employment than older adults during the pandemic (Kochhar \& Barroso, 2020; Soergel, 2020). Asians are more likely to own businesses forced to close due to government mandates (Kochhar, 2020) and are more likely to be health care workers (U.S. Department of Health and Human Services, 2017), a group put under particular strain during the outbreak. With schools and 
daycares closed, those with children at home may have been under increased stress. Married individuals, usually more protected from mental distress, may have found stay-at-home orders increased marital conflict. Future research on the effects of the pandemic should explore these possibilities more fully.

With regard to suicide risk, this demographic pattern can be viewed as somewhat reassuring. The demographic factors of being younger, Asian, married, and with children are each protective against death by suicide, relatively speaking (Calati et al., 2019). Rates are increasing somewhat disproportionately among young people, however (Twenge et al., 2019), suggesting some caution in deriving too much solace from the demographic pattern. Moreover, two other factors, male gender and being separated, showed larger differences by year and are well-known correlates of suicide death.

The two samples were similar in their demographic characteristics, and all demographic groups showed higher mental distress in the 2020 sample than in the 2018 sample. However, the two samples differed in their sampling strategy and administration; the NHIS is a probability sample that uses a home interview and the Luc.id sample used a compensated online panel. We were able to exclude non-internet users from the NHIS sample to make it more comparable to the Luc.id sample. Nevertheless, it is possible that the two samples differed due to the offer of compensation; for example, participants in the Luc.id sample may have been working fewer hours in regular employment. However, given the employment disruptions during the COVID-19 outbreak, any differences in this regard may not be separable from the effects of the pandemic. In the NHIS 2018, the rate of serious mental distress among those looking for work was $10.1 \%$, still considerably lower than the $27.7 \%$ in the 2020 sample. Thus, even if everyone in the 2020 sample was unemployed, which is unlikely, this sample still displayed an extraordinarily high 
level of mental distress compared to the 2018 sample. In addition, even compensated online samples less representative than our panel (e.g., MTurk; Ackerman, 2019; Coppock \& McClellan, 2019) do not consistently differ in the prevalence of clinical disorders, with some studies finding they show lower prevalence, some higher prevalence, and some no difference from probability samples (Chandler \& Shapiro, 2016). Even if some variance is due to sampling, it seems unlikely to be able to explain effect sizes of this magnitude. For example, across several studies comparing MTurk to other samples, the largest identified higher incidence of depression was three times (Arditte et al., 2016); even if that were the case here, serious mental distress would have still nearly tripled from before to during the pandemic. Nevertheless, we cannot rule out the possibility that some of the differences are due to recruitment strategies or the method of administration. These data provide a first glimpse of mental health during the pandemic and should eventually be replicated using a more traditional probability sample which will take more time to collect. Replication involving a more comprehensive and in-depth assessment of mental health also represents a future avenue for inquiry.

In conclusion, mental distress was considerably higher in a nationally representative sample of U.S. adults in late April 2020 compared to a nationally representative sample from 2018. Although these results should be verified through future studies, they provide an early indication that serious mental distress has become strikingly more common during the COVID19 pandemic. 


\section{References}

Ackerman, E. (2019). Entering the academy: Lucid's expansion into academic research. https://luc.id/blog/lucids-expansion-into-academic-research/

Arditte, K. A., Cek, D., Shaw, A. M., \& Timpano, K. R. (2016). The importance of assessing clinical phenomena in Mechanical Turk research. Psychological Assessment, 28, 684691.

Barger, S.D., Messerli-Bürgy, N., \& Barth, J. (2014). Social relationship correlates of major depressive disorder and depressive symptoms in Switzerland: Nationally representative cross-sectional study. BMC Public Health, 14, 273.

Benenson Strategy Group. (2020, April 3). Coronavirus and Americans' mental health: Insights from BSG's pulse of America poll. https://www.bsgco.com/post/coronavirus-andamericans-mental-health-insights-from-bsg-s-pulse-of-america-poll

Bharath, D. (2020, April 22). Suicide, help hotline calls soar in Southern California over coronavirus anxieties. Orange County Register. https://www.ocregister.com/2020/04/19/suicide-help-hotline-calls-soar-in-southerncalifornia-over-coronavirus-anxieties/

Brenan, M. (2020, April 15). Americans say COVID-19 hurting mental health most. Gallup. https://news.gallup.com/poll/308420/americans-say-covid-hurting-mental-health.aspx

Bursztyn, L., Rao, A., Roth, C., \& Yanagizawa-Drott, D. (2020, April 19). Misinformation during a pandemic. Preprint on SSRN: https://papers.ssrn.com/sol3/papers.cfm?abstract_id=3580487 
Calati, R., Ferrari, C., Brittner, M., Oasi, O., Olie, E., Carvalho, A. F., \& Courtet, P. (2019). Suicidal thoughts and behaviors and social isolation: A narrative review of the literature. Journal of Affective Disorders, 15, 653-667.

Chandler, J., \& Shapiro, D. (2016). Conducting clinical research using crowdsourced convenience samples. Annual Review of Clinical Psychology, 12, 53-81.

Chavez, N., Andone, D., Karimi, F. (2020, May 7). California was one of the first states to issue a stay-at-home order. Tomorrow, it'll start to reopen. CNN.com.

Conrad, R., Rayala, H., Diamond, R., Busch, B., \& Kramer, N. (2020, April 7). Expanding telemental health in response to the COVID-19 pandemic. Psychiatric Times. https://www.psychiatrictimes.com/coronavirus/expanding-telemental-health-responsecovid-19-pandemic

Coppock, A. \& McClellan, O. A. (2019). Validating the demographic, political, psychological, and experimental results obtained from a new source of online survey respondents. Research and Politics, 6.

Drapeau, C. W., \& McIntosh, J. L. (2020). U.S.A. suicide: 2018 official final data. https://suicidology.org/wp-content/uploads/2020/02/2018datapgsv2_Final.pdf

Graves, E. (2020, April 28). More people struggling with mental health during coronavirus pandemic. WAFF.com.

Holmes, E. A., O’Connor, R. C., Perry, V. H., Tracey, I., Wessely, S., Arseneault, L. (2020). Multidisciplinary research priorities for the COVID-19 pandemic: A call for action for mental health science. Lancet Psychiatry, April 15, 2020.

Jervis, R. (2020, April 2). 'We're all stressed out': Parenting in a pandemic puts additional stress on families, children. USA Today. 
https://www.usatoday.com/story/news/nation/2020/04/02/parenting-amid-covid-19expert-tips-how-help-kids-home/5109387002/

Johnson, K., \& Link, D. (2020, May 6). Pandemic-fueled surge in gun sales overwhelms FBI background check system; dealers urged to wait on sales. USA Today.

Kavilanz, P., \& Yukevich, V. (2020, May 1). A plan to ease the hand sanitizer shortage could go bust. CNN.com.

Kessler, R. C., Andrews, G., Colpe, L. J., Hiripi, E., Mroczek, D. K., Normand, S.-L. T., . . . Zaslavsky, A. M. (2002). Short screening scales to monitor population prevalences and trends in non-specific psychological distress. Psychological Medicine, 32, 959-976.

Kessler RC, Barker PR, Colpe LJ, Epstein JF, Gfroerer JC, Hiripi E, Howes MJ, Normand SL, Manderscheid RW, Walters EE, Zaslavsky AM. (2003). Screening for serious mental distress in the general population. Archives of General Psychiatry, 60, 184-189.

Kessler, R. C., Green, J. G., Gruber, M. J., Sampson, N. A., Bromet, E., Cuitan, M., Furukawa, T. A., Gureje, O., Hinkov, H., Hu, C.-Y., Lara, C., Lee, S., Mneimneh, Z., Myer, L., Oakley-Browne, M., Posada-Villa, J., Sagar, R., Viana, M. C., \& Zaslavsky, A. M. (2010). Screening for serious mental distress in the general population with the K6 screening scale: Results from the WHO World Mental Health (WMH) survey initiative. International Journal of Methods in Psychiatric Research, 19(Suppl 1), 4-22.

Kochhar, R. (2020, April 23). The financial risk to U.S. business owners posed by COVID-19 outbreak varies by demographic group. Pew Research Center.

Kochhar, R., \& Barroso, A. (2020, March 27). Young workers likely to be hard hit as COVID-19 strikes a blow to restaurants and other service sector jobs. Pew Research Center. 
Lim, M. H., Rodebaugh, T. L., Zyphur, M. J., \& Gleeson, J. F. M. (2016). Loneliness over time: The crucial role of social anxiety. Journal of Abnormal Psychology, 125(5), 620630. https://doi.org/10.1037/abn0000162

Lakhani, N. (2020, April 24). 'A high-risk perfect storm': Loneliness and financial despair take toll on US mental health. The Guardian. https://www.theguardian.com/society/2020/apr/24/mental-health-coronavirus-lockdownhelplines

Levine, M. (2020, April 7). Calls to US helpline jump 891\%, as White House is warned of mental health crisis. https://abcnews.go.com/Politics/calls-us-helpline-jump-891-whitehouse-warned/story?id=70010113

Meehl, P. (1973). Why I do not attend case conferences. In P. E. Meehl (Ed.), Psychodiagnosis: Selected papers (pp. 225- 302). Minneapolis: University of Minnesota Press.

Morath, E. (2020, May 3). April jobs report likely to show highest unemployment rate on record. Wall Street Journal.

National Health Interview Survey (2020). About the National Health Interview Study. https://www.cdc.gov/nchs/nhis/about_nhis.htm

Pfefferbaum, B., \& North, C. (2020). Mental health and the Covid-19 pandemic. New England Journal of Medicine, April 13, 2020. DOI: 10.1056/NEJMp2008017

Prochaska, J. J., Sung, H-Y., Max, W., Shi, Y., \& Ong, M. (2012). Validity study of the K6 scale as a measure of moderate mental distress based on mental health treatment need and utilization. International Journal of Methods in Psychiatric Research, 21, 88-97. 
Reger, M., Stanley, I., \& Joiner, T. (2020). Suicide mortality and COVID-19: A perfect storm? JAMA Psychiatry. Published online April 10, 2020. doi:10.1001/jamapsychiatry.2020.1060

Reyes, A. (2020, April 30). Survey shows parents across New York are struggling amid COVID19 pandemic. WKBW.com. https://www.wkbw.com/news/coronavirus/survey-showsparents-across-new-york-are-struggling-amid-covid-19-pandemic

Robins, E. (1981). The final months. New York: Oxford.

Russell, D., Turner, R.J., \& Joiner, T. (2009). Physical disability and suicidal ideation: A community-based study of risk/protective factors for suicidal thoughts. Suicide \& LifeThreatening Behavior, 39, 440-451.

Shammas, B. (2020, April 24). U.S. coronavirus death toll surpasses 50,000. Washington Post. Soergel, A. (2020, April 3). Virus job losses hit young, minorities first. US News \& World Report.

Spiller, H. A., Ackerman, J. P., Spiller, N. E., \& Casavant, M. J. (2019). Sex- and age-specific increases in suicide attempts by self-poisoning in the United States among youth and young adults from 2000 to 2018. Journal of Pediatrics.

Stanley, I. H., Yancey, J. R., Patrick, C. J., \& Joiner, T. E. (2018). A distinct configuration of MMPI-2-RF scales RCd and RC9/ACT is associated with suicide attempt risk among suicide ideators in a psychiatric outpatient sample. Psychological Assessment, 30, 12491254.

Trout, D. (1980). The role of social isolation in suicide. Suicide \& Life-Threatening Behavior.

Twenge, J. M., Cooper, A. B., Joiner, T. E., Duffy, M. E., \& Binau, S. G. (2019). Age, period, and cohort trends in mood disorder indicators and suicide-related outcomes in a 
nationally representative dataset, 2005-2017. Journal of Abnormal Psychology, 128, 185199. $10,10-23$.

U.S. Department of Health and Human Services, Health Resources and Services Administration, National Center for Health Workforce Analysis (2017). Sex, race, and ethnic diversity of U.S, Health Occupations (2011-2015). Rockville, Maryland.

Van Orden, K., Witte, T., Cukrowicz, K., Braithwaite, S., Selby, E., \& Joiner, T. (2010). The interpersonal theory of suicide. Psychological Review, 117, 575-600.

Zarefsky, M. (2020, April 30). How to combat COVID-19's disparate mental health impact. American Medical Association. https://www.ama-assn.org/delivering-care/health-equity/howcombat-covid-19-s-disparate-mental-health-impact 
Table 1: Demographic characteristics, NHIS 2018 internet users $(n=19,330)$ and online nationally representative sample April $2020(n=2,032)$

\begin{tabular}{|c|c|c|}
\hline & NHIS 2018 & Luc.id 2020 \\
\hline Age & $44.73(16.97)$ & $44.93(16.67)$ \\
\hline \multicolumn{3}{|l|}{ Age group } \\
\hline $18-29$ & $23.9 \%$ & $22.5 \%$ \\
\hline $30-44$ & $28.0 \%$ & $28.7 \%$ \\
\hline $45-59$ & $25.3 \%$ & $25.0 \%$ \\
\hline $60+$ & $22.9 \%$ & $23.8 \%$ \\
\hline Gender: \% female & $51.9 \%$ & $51.0 \%$ \\
\hline \multicolumn{3}{|l|}{ Race } \\
\hline White & $78.7 \%$ & $73.8 \%$ \\
\hline Black & $11.3 \%$ & $11.2 \%$ \\
\hline Asian & $6.4 \%$ & $6.8 \%$ \\
\hline Other & $3.5 \%$ & $8.1 \%$ \\
\hline Hispanic & $14.7 \%$ & $11.7 \%$ \\
\hline \multicolumn{3}{|l|}{ Region } \\
\hline Northeast & $17.2 \%$ & $20.5 \%$ \\
\hline Midwest & $22.5 \%$ & $18.6 \%$ \\
\hline South & $36.0 \%$ & $37.5 \%$ \\
\hline West & $24.2 \%$ & $23.4 \%$ \\
\hline \multicolumn{3}{|l|}{ Marital status } \\
\hline Married spouse present & $52.7 \%$ & $45.4 \%$ \\
\hline Living with partner & $7.9 \%$ & $9.7 \%$ \\
\hline Divorced or widowed & $11.7 \%$ & $13.4 \%$ \\
\hline Never married & $24.9 \%$ & $29.0 \%$ \\
\hline Separated or spouse not present & $2.7 \%$ & $2.5 \%$ \\
\hline Children $<18$ in household & $36.6 \%$ & $35.7 \%$ \\
\hline
\end{tabular}

NOTE: NHIS 2018 data are weighted. 
Table 2: Kessler-6 means, 2018 vs. 2020

\begin{tabular}{|c|c|c|c|}
\hline & NHIS 2018 & Luc.id 2020 & $d(95 \% \mathrm{CI})$ \\
\hline All & $2.79(3.85) 19330$ & $8.91(6.21) 2032$ & $1.48(1.43,1.53)$ \\
\hline \multicolumn{4}{|l|}{ Age group } \\
\hline $18-29$ & $3.13(3.92) 3392$ & $10.76(5.77) 458$ & $1.82(1.72,1.93)$ \\
\hline $30-44$ & $3.00(4.02) 5232$ & $10.82(6.42) 583$ & $1.81(1.72,1.90)$ \\
\hline $45-59$ & $2.75(3.90) 4916$ & $8.52(5.87) 508$ & $1.40(1.30,1.49)$ \\
\hline $60+$ & $2.21(3.41) 5790$ & $5.26(4.86) 483$ & $0.86(.77, .96)$ \\
\hline \multicolumn{4}{|l|}{ Gender } \\
\hline Female & $3.10(4.05) 10566$ & $8.82(5.96) 1037$ & $1.34(1.28,1.41)$ \\
\hline Male & $2.46(3.59) 8764$ & $9.01(6.46) 995$ & $1.65(1.58,1.72)$ \\
\hline \multicolumn{4}{|l|}{ Race } \\
\hline White & $2.80(3.86) 15630$ & $8.81(6.25) 1483$ & $1.46(1.40,1.51)$ \\
\hline Black & $2.72(3.79) 1982$ & $8.53(6.22) 226$ & $1.42(1.27,1.56)$ \\
\hline Asian & $2.23(3.22) 1063$ & $9.87(5.92) 137$ & $2.11(1.91,2.30)$ \\
\hline Other & $3.84(4.63) 655$ & $9.80(5.98) 163$ & $1.21(1.03,1.39)$ \\
\hline \multicolumn{4}{|l|}{ Hispanic ethnicity } \\
\hline Yes & $2.80(3.81) 2142$ & $10.00(6.14) 237$ & $1.76(1.61,1.90)$ \\
\hline No & $2.74(4.08) 17188$ & $8.78(6.21) 1785$ & $1.40(1.35,1.45)$ \\
\hline \multicolumn{4}{|l|}{ Region } \\
\hline Northeast & $2.64(3.62) 3108$ & $9.00(5.98) 417$ & $1.60(1.49,1.71)$ \\
\hline Midwest & $2.88(3.87) 4601$ & $8.20(6.04) 378$ & $1.31(1.20,1.41)$ \\
\hline South & $2.74(3.89) 6860$ & $9.24(6.39) 761$ & $1.55(1.47,1.62)$ \\
\hline West & $2.89(3.92) 4761$ & $8.87(6.21) 476$ & $1.43(1.33,1.53)$ \\
\hline \multicolumn{4}{|l|}{ Marital status } \\
\hline Married spouse present & $2.30(3.30) 8941$ & $8.61(6.50) 923$ & $1.70(1.63,1.77)$ \\
\hline Living with partner & $3.48(4.23) 1230$ & $9.68(5.31) 197$ & $1.41(1.25,1.57)$ \\
\hline Divorced or widowed & $3.22(4.35) 3833$ & $7.35(5.96) 273$ & $0.92(.80,1.05)$ \\
\hline Never married & $3.28(4.24) 4596$ & $9.48(5.83) 588$ & $1.39(1.30,1.48)$ \\
\hline $\begin{array}{l}\text { Separated or spouse not } \\
\text { present }\end{array}$ & $3.92(4.98) 704$ & $13.30(6.61) 50$ & $1.84(1.54,2.14)$ \\
\hline \multicolumn{4}{|l|}{$\begin{array}{l}\text { Children }<18 \text { in } \\
\text { household }\end{array}$} \\
\hline Yes & $2.69(3.70) 5874$ & $10.68(6.48) 719$ & $1.95(1.87,2.04)$ \\
\hline No & $2.85(3.93) 13456$ & $7.92(5.81) 1296$ & $1.23(1.17,1.29)$ \\
\hline
\end{tabular}


NOTES: Numbers within cells are means (SDs), and $n$ 's. NHIS 2018 data are weighted. $d=$ difference in standard deviations. 
Table 3: Percent with serious mental distress and percent with moderate or serious mental distress, Kessler-6, 2018 vs. 2020

\begin{tabular}{|c|c|c|c|c|c|c|}
\hline & $\begin{array}{l}\text { Serious } \\
\text { distress } \\
\text { NHIS } 2018\end{array}$ & $\begin{array}{l}\text { Serious } \\
\text { distress } \\
\text { Luc.id } 2020\end{array}$ & RR $(95 \% \mathrm{CI})$ & $\begin{array}{l}\text { Moderate or } \\
\text { serious } \\
\text { distress } \\
\text { NHIS } 2018\end{array}$ & $\begin{array}{l}\text { Moderate or } \\
\text { serious } \\
\text { distress } \\
\text { Luc.id } 2020\end{array}$ & $\mathrm{RR}(95 \% \mathrm{CI})$ \\
\hline All & $\begin{array}{l}3.4 \% \\
(661,18772)\end{array}$ & $\begin{array}{l}27.7 \% \\
(562,1470)\end{array}$ & $\begin{array}{l}8.13 \\
(7.34,9.01)\end{array}$ & $\begin{array}{l}22.0 \% \\
(4275, \\
15158)\end{array}$ & $\begin{array}{l}70.4 \% \\
(1431,601)\end{array}$ & $\begin{array}{l}3.20 \\
(3.08,3.33)\end{array}$ \\
\hline \multicolumn{7}{|c|}{ Age group } \\
\hline $18-29$ & $\begin{array}{l}3.6 \%(122, \\
3270)\end{array}$ & $\begin{array}{l}38.4 \%(176, \\
282)\end{array}$ & $\begin{array}{l}10.68 \\
(8.67,13.17)\end{array}$ & $\begin{array}{l}26.3 \% \\
(892,2500)\end{array}$ & $\begin{array}{l}82.3 \%(458) \\
(377,81)\end{array}$ & $\begin{array}{l}3.13 \\
(2.92,3.36)\end{array}$ \\
\hline $30-44$ & $\begin{array}{l}3.8 \% \\
(199,5033)\end{array}$ & $\begin{array}{l}37.2 \% \\
(217,366)\end{array}$ & $\begin{array}{l}9.79 \\
(8.24,11.63)\end{array}$ & $\begin{array}{l}23.8 \% \\
(1245,3987)\end{array}$ & $\begin{array}{l}80.5 \% \\
(369,89)\end{array}$ & $\begin{array}{l}3.39 \\
(3.17,3.62)\end{array}$ \\
\hline $45-59$ & $\begin{array}{l}3.8 \% \\
(187,4729)\end{array}$ & $\begin{array}{l}24.6 \%(508) \\
(125,383)\end{array}$ & $\begin{array}{l}6.47 \\
(5.26,7.96)\end{array}$ & $\begin{array}{l}21.1 \% \\
(1037,3879)\end{array}$ & $\begin{array}{l}71.1 \% \\
(361,147)\end{array}$ & $\begin{array}{l}3.37 \\
(3.12,3.64)\end{array}$ \\
\hline $60+$ & $\begin{array}{l}2.1 \% \\
(122,5668)\end{array}$ & $\begin{array}{l}9.1 \% \\
(44,439)\end{array}$ & $\begin{array}{l}4.32 \\
(2.10,6.02)\end{array}$ & $\begin{array}{l}16.4 \% \\
(950,4840)\end{array}$ & $\begin{array}{l}46.4 \% \\
(224,259)\end{array}$ & $\begin{array}{l}2.83 \\
(2.83,3.16)\end{array}$ \\
\hline \multicolumn{7}{|l|}{ Gender } \\
\hline Female & $\begin{array}{l}4.2 \% \\
(444,10122)\end{array}$ & $\begin{array}{l}27.2 \% \\
(282,755)\end{array}$ & $\begin{array}{l}6.47 \\
(5.65,7.41)\end{array}$ & $\begin{array}{l}24.4 \% \\
(2578,7988)\end{array}$ & $\begin{array}{l}71.4 \% \\
(740,297)\end{array}$ & $\begin{array}{l}2.92 \\
(2.78,3.08)\end{array}$ \\
\hline Male & $\begin{array}{l}2.4 \% \\
(210,8554)\end{array}$ & $\begin{array}{l}28.1 \% \\
(268,727)\end{array}$ & $\begin{array}{l}11.24 \\
(9.50,13.30)\end{array}$ & $\begin{array}{l}19.4 \% \\
(1700,7064)\end{array}$ & $\begin{array}{l}69.5 \% \\
(664,291)\end{array}$ & $\begin{array}{l}3.58 \\
(3.38,3.81)\end{array}$ \\
\hline \multicolumn{7}{|l|}{ Race } \\
\hline White & $\begin{array}{l}3.4 \% \\
(531,15099)\end{array}$ & $\begin{array}{l}26.9 \% \\
(402,1091)\end{array}$ & $\begin{array}{l}7.93 \\
(7.04,8.92)\end{array}$ & $\begin{array}{l}22.0 \% \\
(3439,2191)\end{array}$ & $\begin{array}{l}69.5 \%(1483) \\
(1031,452)\end{array}$ & $\begin{array}{l}2.12 \\
(2.03,2.22)\end{array}$ \\
\hline Black & $\begin{array}{l}3.0 \% \\
(59,1923)\end{array}$ & $\begin{array}{l}28.3 \% \\
(64,162)\end{array}$ & $\begin{array}{l}9.51 \\
(6.87,13.18)\end{array}$ & $\begin{array}{l}21.8 \% \\
(432,1550)\end{array}$ & $\begin{array}{l}66.8 \% \\
(151,75)\end{array}$ & $\begin{array}{l}3.19 \\
(2.92,3.49)\end{array}$ \\
\hline Asian & $\begin{array}{l}1.6 \% \\
(17,1046)\end{array}$ & $\begin{array}{l}27.0 \% \\
(37,100)\end{array}$ & $\begin{array}{l}16.89 \\
(9.78,29.15)\end{array}$ & $\begin{array}{l}18.1 \% \\
(192,871)\end{array}$ & $\begin{array}{l}78.8 \% \\
(108,29)\end{array}$ & $\begin{array}{l}4.36 \\
(3.73,5.09)\end{array}$ \\
\hline Other & $\begin{array}{l}7.3 \% \\
(48,607)\end{array}$ & $\begin{array}{l}34.4 \% \\
(56,107)\end{array}$ & $\begin{array}{l}4.69 \\
(3.32,6.62)\end{array}$ & $\begin{array}{l}30.6 \% \\
(200,455)\end{array}$ & $\begin{array}{l}77.3 \% \\
(126,37)\end{array}$ & $\begin{array}{l}2.53 \\
(2.20,2.92)\end{array}$ \\
\hline \multicolumn{7}{|l|}{$\begin{array}{l}\text { Hispanic } \\
\text { ethnicity }\end{array}$} \\
\hline Yes & $3.8 \%$ & $35.0 \%$ & 9.26 & $21.7 \%$ & $78.1 \%$ & 3.60 \\
\hline
\end{tabular}




\begin{tabular}{|c|c|c|c|c|c|c|}
\hline & $(81,2061)$ & $(83,154)$ & $(3.03,12.19)$ & $(465,1677)$ & $(185,52)$ & $(3.24,3.99)$ \\
\hline No & $\begin{array}{l}3.3 \% \\
(567,16621)\end{array}$ & $\begin{array}{l}26.8 \% \\
(478,1307)\end{array}$ & $\begin{array}{l}8.12 \\
(7.26,9.08)\end{array}$ & $\begin{array}{l}22.1 \% \\
(3799,13389)\end{array}$ & $\begin{array}{l}69.5 \% \\
(1241,544)\end{array}$ & $\begin{array}{l}3.15 \\
(3.02,3.28)\end{array}$ \\
\hline \multicolumn{7}{|l|}{ Region } \\
\hline Northeast & $\begin{array}{l}2.7 \% \\
(84,3024)\end{array}$ & $\begin{array}{l}25.4 \% \\
(106,311)\end{array}$ & $\begin{array}{l}9.41 \\
(7.20,12.29)\end{array}$ & $\begin{array}{l}20.4 \% \\
(634,2474)\end{array}$ & $\begin{array}{l}72.9 \% \\
(304,113)\end{array}$ & $\begin{array}{l}3.57 \\
(3.26,3.91)\end{array}$ \\
\hline Midwest & $\begin{array}{l}3.4 \% \\
(156,4445)\end{array}$ & $\begin{array}{l}24.3 \% \\
(92,286)\end{array}$ & $\begin{array}{l}7.18 \\
(5.67,9.08)\end{array}$ & $\begin{array}{l}22.4 \% \\
(1031,3570)\end{array}$ & $\begin{array}{l}65.7 \% \\
(248,130)\end{array}$ & $\begin{array}{l}2.93 \\
(2.67,3.21)\end{array}$ \\
\hline South & $\begin{array}{l}3.4 \% \\
(233,6627)\end{array}$ & $\begin{array}{l}31.4 \% \\
(239,522)\end{array}$ & $\begin{array}{l}9.25 \\
(7.85,10.90)\end{array}$ & $\begin{array}{l}21.7 \% \\
(1489,5371)\end{array}$ & $\begin{array}{l}70.2 \% \\
(534,227)\end{array}$ & $\begin{array}{l}3.23 \\
(3.03,3.45)\end{array}$ \\
\hline West & $\begin{array}{l}3.7 \% \\
(176,4585)\end{array}$ & $\begin{array}{l}26.3 \% \\
(125,351)\end{array}$ & $\begin{array}{l}7.10 \\
(5.76,8.80)\end{array}$ & $\begin{array}{l}23.4 \% \\
(1114,3647)\end{array}$ & $\begin{array}{l}72.3 \% \\
(344,132)\end{array}$ & $\begin{array}{l}3.09 \\
(2.86,3.33)\end{array}$ \\
\hline \multicolumn{7}{|l|}{ Marital status } \\
\hline $\begin{array}{l}\text { Married } \\
\text { spouse } \\
\text { present }\end{array}$ & $\begin{array}{l}1.9 \% \\
(170,8771)\end{array}$ & $\begin{array}{l}25.0 \% \\
(231,692)\end{array}$ & $\begin{array}{l}13.16 \\
(10.93, \\
15.86)\end{array}$ & $\begin{array}{l}17.7 \% \\
(1583,7358)\end{array}$ & $\begin{array}{l}66.9 \% \\
(617,306)\end{array}$ & $\begin{array}{l}3.78 \\
(3.54,4.02)\end{array}$ \\
\hline $\begin{array}{l}\text { Living with } \\
\text { partner }\end{array}$ & $\begin{array}{l}4.9 \% \\
(60,1170)\end{array}$ & $\begin{array}{l}30.5 \% \\
(60,137)\end{array}$ & $\begin{array}{l}6.24 \\
(4.51,8.64)\end{array}$ & $\begin{array}{l}28.6 \% \\
(352,878)\end{array}$ & $\begin{array}{l}82.2 \% \\
(162,35)\end{array}$ & $\begin{array}{l}2.90 \\
(2.58,3.21)\end{array}$ \\
\hline $\begin{array}{l}\text { Divorced or } \\
\text { widowed }\end{array}$ & $\begin{array}{l}5.1 \% \\
(195,3638)\end{array}$ & $\begin{array}{l}22.0 \% \\
(60,213)\end{array}$ & $\begin{array}{l}4.32 \\
(3.32,5.61)\end{array}$ & $\begin{array}{l}24.9 \% \\
(954,2879)\end{array}$ & $\begin{array}{l}59.0 \% \\
(161,112)\end{array}$ & $\begin{array}{l}2.37 \\
(2.12,2.65)\end{array}$ \\
\hline $\begin{array}{l}\text { Never } \\
\text { married }\end{array}$ & $\begin{array}{l}4.6 \% \\
(211,4385)\end{array}$ & $\begin{array}{l}31.0 \% \\
(182,406)\end{array}$ & $\begin{array}{l}6.74 \\
(5.64,8.06)\end{array}$ & $\begin{array}{l}26.7 \% \\
(1227,3369)\end{array}$ & $\begin{array}{l}76.0 \% \\
(447,141)\end{array}$ & $\begin{array}{l}2.85 \\
(2.67,3.04)\end{array}$ \\
\hline $\begin{array}{l}\text { Separated or } \\
\text { spouse not } \\
\text { present }\end{array}$ & $\begin{array}{l}7.9 \% \\
(56,648)\end{array}$ & $\begin{array}{l}58.0 \% \\
(29,21)\end{array}$ & $\begin{array}{l}7.30 \\
(5.17,10.29)\end{array}$ & $\begin{array}{l}31.3 \% \\
(220,484)\end{array}$ & $\begin{array}{l}88.0 \% \\
(44,6)\end{array}$ & $\begin{array}{l}2.82 \\
(2.42,3.27)\end{array}$ \\
\hline \multicolumn{7}{|l|}{$\begin{array}{l}\text { Children }<18 \\
\text { in household }\end{array}$} \\
\hline Yes & $\begin{array}{l}3.1 \% \\
(182,5692)\end{array}$ & $\begin{array}{l}37.0 \% \\
(266,453)\end{array}$ & $\begin{array}{l}11.94 \\
(10.05 \\
14.18)\end{array}$ & $\begin{array}{l}21.4 \% \\
(1257,4617)\end{array}$ & $\begin{array}{l}79.4 \% \\
(571,148)\end{array}$ & $\begin{array}{l}3.71 \\
(3.49,3.95)\end{array}$ \\
\hline No & $\begin{array}{l}3.5 \% \\
(471,12985)\end{array}$ & $\begin{array}{l}22.2 \% \\
(288,1008)\end{array}$ & $\begin{array}{l}6.35 \\
(5.55,7.27)\end{array}$ & $\begin{array}{l}22.4 \% \\
(3014, \\
10442)\end{array}$ & $\begin{array}{l}65.5 \% \\
(849,447)\end{array}$ & $\begin{array}{l}2.92 \\
(2.78,3.08)\end{array}$ \\
\hline
\end{tabular}

NOTES: NHIS 2018 data are weighted. RR = relative risk. RR's with a 95\% CI not including 1 are in bold. 
Table 4: Item means, Kessler-6, 2018 vs. 2020

\begin{tabular}{|l|l|l|l|}
\hline & NHIS 2018 & Luc.id 2020 & $d(95 \%$ CI $)$ \\
\hline Sad & $.38(.77)$ & $1.48(1.23)$ & $1.33(1.29,1.38)$ \\
\hline Nervous & $.70(.99)$ & $1.77(1.16)$ & $1.06(1.02,1.11)$ \\
\hline Restless & $.71(1.07)$ & $1.73(1.20)$ & $.94(.90, .99)$ \\
\hline Hopeless & $.23(.65)$ & $1.24(1.27)$ & $1.381 .33,1.43)$ \\
\hline Everything an effort & $.59(1.03)$ & $1.61(1.25)$ & $.97(.92,1.02)$ \\
\hline Worthless & $.18(.61)$ & $1.07(1.33)$ & $1.25(1.21,1.30)$ \\
\hline
\end{tabular}

NOTES: Numbers within cells are means and SDs. NHIS 2018 data are weighted. $n=19,330$ for 2018 and $n=2,032$ for 2020 . The K6 is scored on a scale of $0=$ none; $1=$ a little; $2=$ some; $3=$ most; 4 = all. 


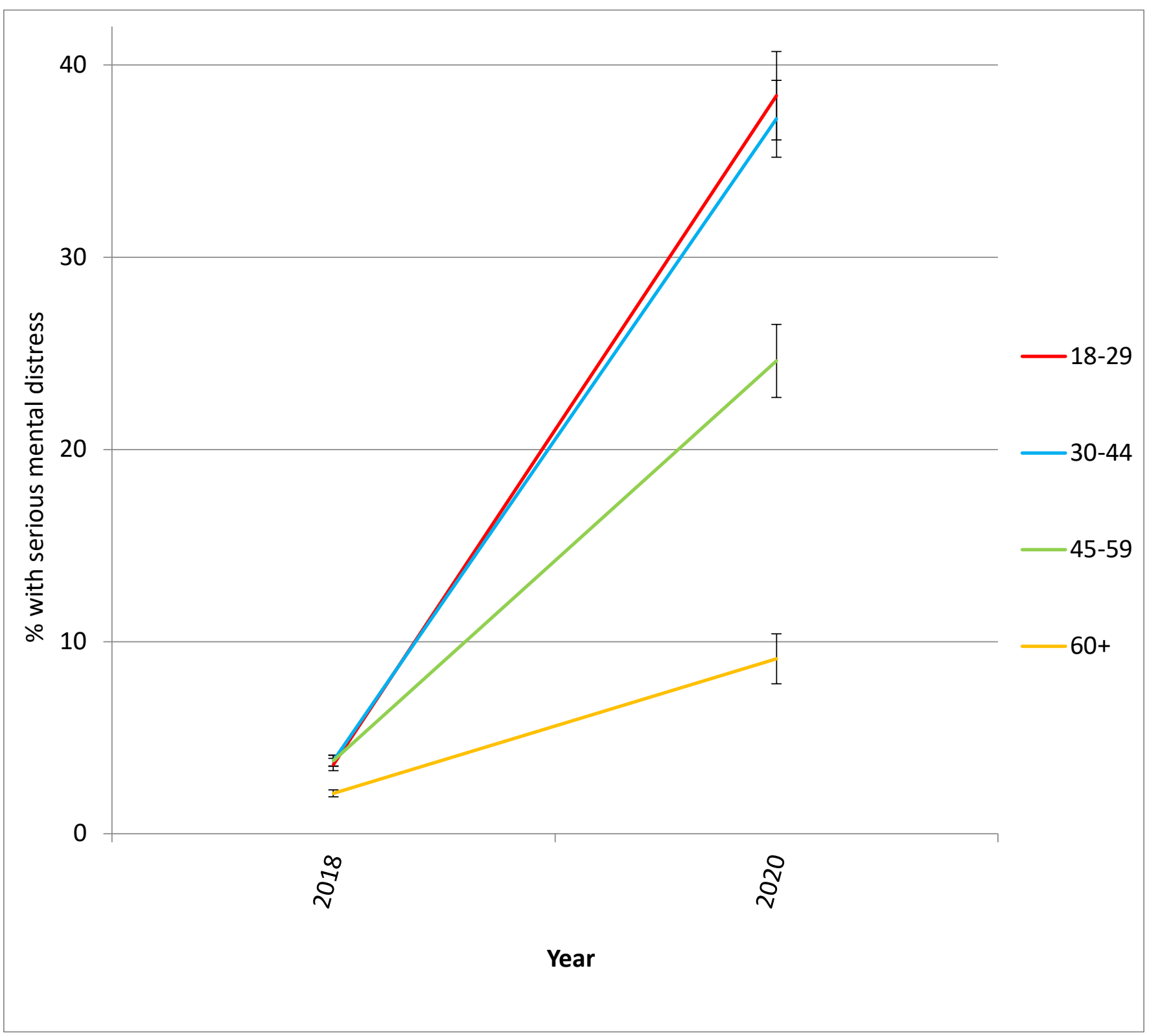

Figure 1: Percentage with serious mental distress by age group, U.S. adults, 2018 vs. 2020. Error bars are plus or minus one SE. 


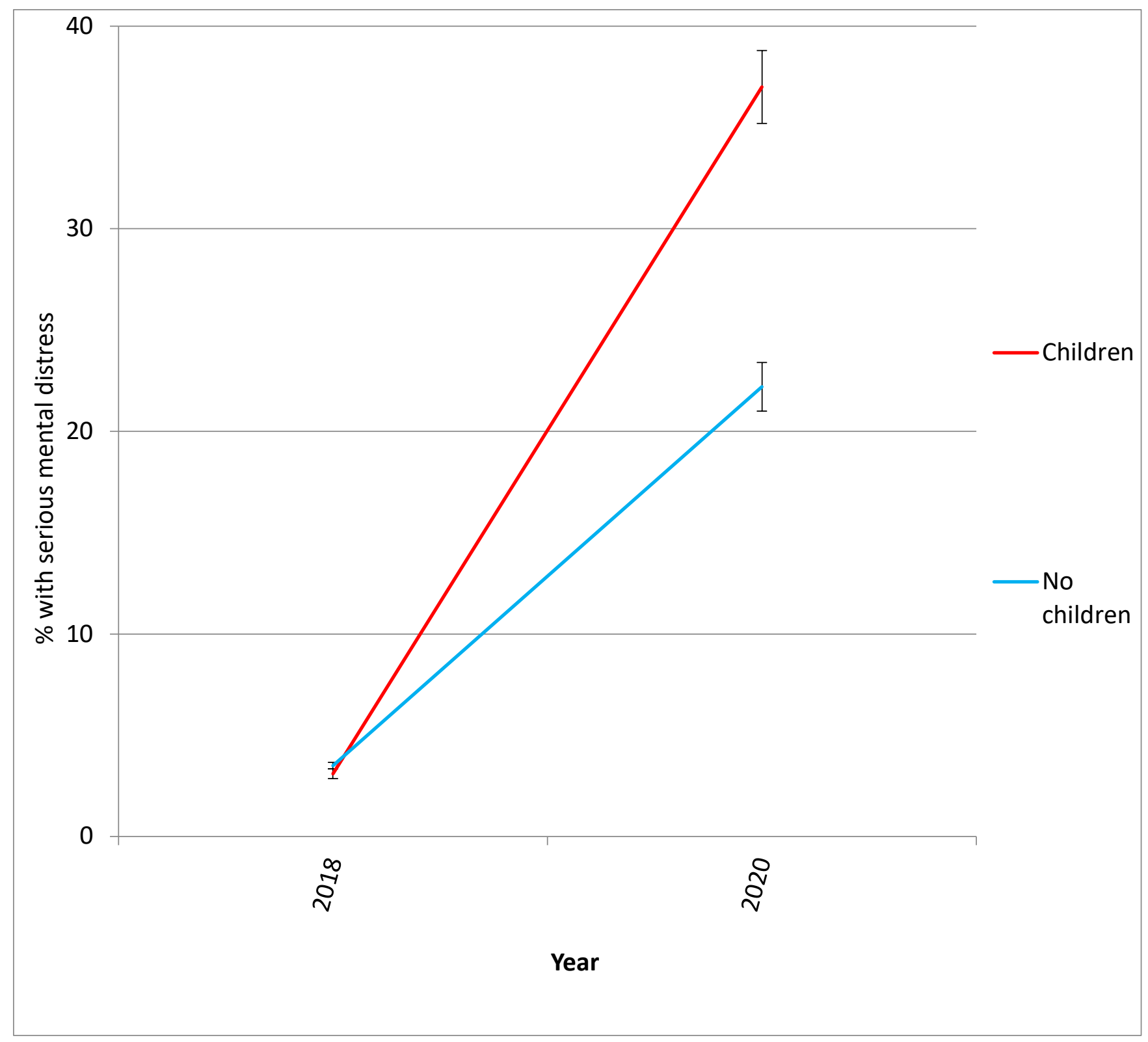

Figure 2: Percentage with serious mental distress by having children in the household vs. no children in the household, U.S. adults, 2018 vs. 2020. Error bars are plus or minus one SE. 


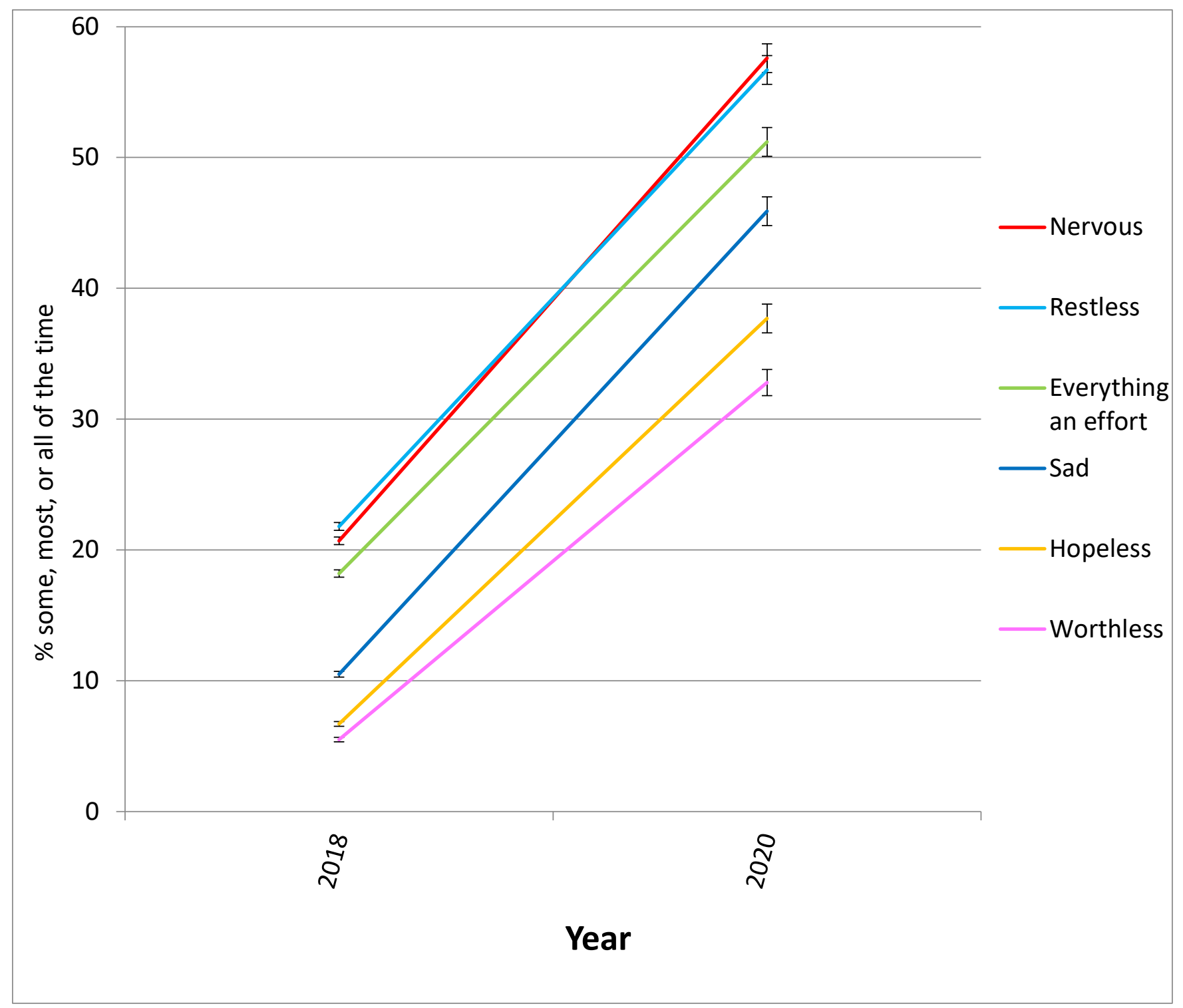

Figure 3: Percentage reporting specific symptoms of mental distress at least some of the time during the last 30 days, U.S. adults, 2018 vs. 2020. Error bars are plus or minus one SE. 